УДК 37.012

DOI 10.11603/me.2414-5998.2019.4.10870

Г. В. Білавич ${ }^{1}$

ORCID https://orcid.org/0000-0002-1555-0932

І. В. Білавич ${ }^{2}$

ORCID https://orcid.org/0000-0003-4561-4690

М. П. Пантюк ${ }^{3}$

ORCID https://orcid.org/0000-0001-7336-6714

ResearcherID X-8503-2019

Б. П. Савчук ${ }^{1}$

ORCID https://orcid.org/0000-0003-2256-0845

Scopus Author ID 57211269907

Н. О. Федчишин ${ }^{4}$

ORCID https://orcid.org/0000-0002-0909-4424

ResearcherID Q-5422-2016

Scopus Author ID 57202833382

${ }^{1}$ ДВНЗ «Прикарпатський національний університет імені Василя Стефаника»

${ }^{2}$ Варшавський медичний університет, Варшава, Республіка Польща

${ }^{3}$ Дрогобицький педагогічний університет імені Івана Франка

${ }^{4}$ Тернопільський національний медичний університет імені І. Я. Горбачевського МОЗ Украӥни

\title{
КУРОРТНО-РЕКРЕАЦЙНИЙ ПОТЕНЦІАЛ КАРПАТ ЯК ЧИННИК ЗДОРОВ'ЯЗБЕРЕЖЕННЯ ДІТЕЙ ТА ДОРОСЛИХ (ПОЧАТОК ХХ СТОРІЧЧЯ)
}

\author{
H. V. Bilavych ${ }^{1}$, I. V. Bilavych ${ }^{2}$, M. P. Pantyuk ${ }^{3}$, B. P. Savchuk ${ }^{1}$, N. O. Fedchyshyn ${ }^{4}$ \\ ${ }^{1}$ Vasyl Stefanyk Precarpathian National University \\ ${ }^{2}$ Warsaw Medical University, Warsaw, Poland \\ ${ }^{3}$ Ivan Franko Drohobych State Pedagogical University \\ ${ }^{4}$ I. Horbachevsky Ternopil National Medical University

\section{RESORT AND RECREATION POTENTIAL OF THE CARPATHIANS AS A FACTOR OF HEALTH CARE OF CHILDREN AND ADULTS (THE BEGINNING OF THE XX CENTURY)}

\begin{abstract}
Анотація. На початку XX ст. у Карпатському регіоні склалася система масового громадського медичного просвітництва, що охоплювало всі напрями системи медичної опіки (санітарно-гігієнічний сегмент, здоров’язбереження та тіловиховання, рух тверезості тощо), яка постійно еволюціонувала та вдосконалювалася. Означені напрями праці були реальним внеском у збереження генофонду українського народу. Створена система лікувально-профілактичних (диспансери, амбулаторії, шпиталі, лабораторії) та консультативних («порадні») закладів засвідчила важливість організації суспільної медичної опіки українців, тут могли отримати безкоштовну (чи за символічну оплату) найменш незахищені (та найбільш вразливі до соціальних катаклізмів) верстви українства (діти, учасники національно-визвольних змагань українців, інваліди, удовиці, сироти, селянство, українське вчительство, студентство та ін.). Складником філософії здоров’язбереження українства була ідея тіловиховання. Ефективним засобом і формою здоров'язбереження в Галичині стало оздоровлення дітей та дорослих за умов гірської місцевості в «оселях», «півоселях», «живцях» та інших суспільних закладах, що виконували оздоровчі й лікувальні функції. Українські громадські (зазвичай станові) товариства вагомо спричинилися до організації відпочинку для своїх членів, а також забезпечення оздоровлення (зазвичай міських дітей) у Карпатах.
\end{abstract}

Ключові слова: курортно-рекреаційний потенціал Карпат; діти; дорослі; суспільна медична опіка; оздоровлення; здоров'язбереження; спорт.

(ㄷ Г. В. Білавич, І. В. Білавич, М. П. Пантюк та ін. 
Abstract. In the early twentieth century in the Carpathian region, a system of mass public medical education was developed, covering all areas of the medical care system (sanitary and hygiene segment, health and physical education, movement for sobriety, etc.), which has been constantly evolving and improving. These areas of work were a real contribution to the conservation of the gene pool of the Ukrainian people. The established system of medical-preventive (clinics, dispensaries, hospitals, laboratories) and consultative establishments confirmed the importance of organizing public medical care of Ukrainians; the most vulnerable of the Ukrainian population (children, participants of national liberation struggle of Ukrainians, disabled people, widows, orphans, peasants, Ukrainian teaching, students, etc.) could receive free medical help (or for a small fee) here. The idea of physical education was an integral part of the philosophy of Ukrainian health conservation. An effective remedy and form of health care in Galicia was the rehabilitation of children and adults in the mountainous terrain in "settlements", "villages" and other public institutions performing health and medical functions. Ukrainian public (usually class) societies made a significant contribution to the organization of recreation for their members, as well as the provision of health (usually urban children) in the Carpathians. The purpose of the study is to trace the development of public medical care of children and adults based on a comprehensive analysis of socio-cultural and educational processes in the Carpathian region at the end of the XIX - beginning of the XX centuries; to express resort and recreational potential of the Carpathians; to determine the possibilities of using this historical experience in the current conditions of reforming the education and medicine systems in Ukraine.

Key words: resort and recreational potential of the Carpathians; children; adults; public medical care; health improvement; health care; sports.

Вступ. Актуальність порушеної в назві статті теми зумовлена низкою суспільно-політичних, соціально-економічних, культурно-освітніх, науково-теоретичних чинників. Вони увиразнюються в історико-педагогічній, науковій, теоретичній, практичній площинах, а також у національному та державному вимірах. Історико-педагогічний аспект актуальності досліджуваної проблеми визначається потребою грунтовного осмислення історії становлення і розвитку суспільної системи охорони здоров'я в Карпатському регіоні на початку XX ст., які були досі маловідомі, замовчувані або представлені суб'єктивно. Це вимагає переосмислення закономірностей, принципів, змісту, методів, форм, механізмів медичної опіки дітей і дорослих крізь призму різних галузей педагогіки (історії педагогіки, соціальної педагогіки, опікунської педагогіки) i міждисциплінарного підходу (медицина, історична наука тощо).

У національно-державному вимірі актуальність дослідження визначається викликами, зумовленими зростанням вимог до якості здоров'я та фінансовими і технологічними можливостями їхнього задоволення за умов об'єктивних і суб'єктивних труднощів, з якими в Україні впроваджується реформа медицини. Ведення військових дій на сході держави актуалізує потребу в медичній опіці військовиків, реабілітації воїнів, звільнених у запас, інвалідів, переселенців, мешканців прифронтових зон, удів і сиріт, а також у профілактиці недуг, санітарно-гігієнічному просвітництві, оздоровленні цих категорій громадян. У зв'язку з цим постає нагальна потреба в підготовці медичних працівників до організації медичної опіки цивільного населення за умов війни та випрацювання нових освітніх програм для підготовки медиків-волонтерів, військових медиків.

Посилення соціально-економічного занепаду й культурної деградації українського села, процеси його старіння, подекуди вимирання, поширення хронічних захворювань, несприятливих демографічних тенденцій (від'ємний природний приріст населення, демографічне старіння, зростання наркотичної залежності та зловживанням алкоголем, тютюнокурінням) гальмують реалізацію державотворчого потенціалу України, посилюють ризики втрати генофонду української нації. Одним зі шляхів виходу з цієї ситуації $є$ виховання «лікарясуспільника» як людини-патріота, громадянина, громадського просвітника, волонтера, здатного вдосконалити сільську медицину, зробити її доступною і високоякісною.

Тому за сучасних умов актуалізується історичний досвід діяльності українських культурно-освітніх, дитячо-юнацьких, благодійницьких, інших громадських організацій Галичини наприкінці XIX - початку XX ст., які виробили ефективні форми, оригінальні механізми, засоби масового медичного просвітництва й опіки дітей та дорослих, мобілізували національний потенціал українства на розв' язання життєво важливих завдань щодо його здоров'язбереження.

Мета статті - на основі комплексного аналізу соціокультурних і освітніх процесів у Карпатському регіоні наприкінці XIX - на початку XX ст. простежити розвиток суспільної медичної опіки дітей і дорослих, увиразнити курортно-рекреаційний потенціал Карпат та визначити можливості використання цього історичного досвіду за сучасних умов реформування систем освіти і медицини в Україні. 
Теоретична частина. Важливо зазначити, що ще за досліджуваного періоду науковці зосереджували увагу на актуальних проблемах охорони здоров’я населення Галичини за часів Другої Речі Посполитої, зокрема польські дослідники (М. Гродецький [18]) писали про боротьбу з інфекційними недугами, туберкульозом, перспективні напрями розвитку медицини на «землях польських» окреслив Т. Гілярович [17], він проаналізував державну політику Другої Речі Посполитої в ділянці організації охорони здоров’я, державної медичної служби з погляду «права санітарного». Окремі джерела, що репрезентують писемні наукові праці, окреслюють появу нового напряму в розвитку тодішньої медицини - становлення і розвиток лікувально-курортної справи. Виокремлюємо надбання українських (до прикладу, Є. Озаркевич [12], який докладно проаналізував «кліматичні станції» для оздоровлення та профілактики захворювань на Гуцульщині (Дора, Жаб’є, Космач, Підлюте) та подав важливі практичні рекомендації щодо розвитку санаторно-курортної справи в Галичині), а також польських учених: відомого лікаря та державного урядовця, бальнеолога, економіста М. Кацпжака [19], С. Лещицького [20-21], їхні праці присвячені курортно-рекреаційному потенціалу Карпат, до уваги взято економічний бік курортно-санаторної справи, з метою розвитку лікувального туризму подано опис лікувальних властивостей мінеральних вод у карпатських «кліматичних станціях», інформацію про санаторне лікування, здійснено економічно-комерційний прогноз щодо розвитку курортної справи в Галичині.

Українські громадські товариства кінця XIX - початку XX ст. створили систему суспільної медичної опіки, про це більш докладно - у нашій окремій публікації [2]. Окрім мандрівництва і таборування, засобом і формою здоров'язбереження в Галичині стало оздоровлення дітей та дорослих в «оселях», «півоселях», «живцях» та інших суспільних закладах, що виконували оздоровлювальні й лікувальні функції. Українські громадські (зазвичай станові) товариства вагомо спричинилися до організації відпочинку для своїх членів, а також забезпечення оздоровлення (зазвичай міських дітей) у гірській місцевості. Зведення «осель» відбувалося за складних умов фінансової скрути, вимагало, окрім іншого, зусиль, спрямованих на подолання численних перешкод, зокрема й юридичного порядку. На увагу заслуговує «подвиг в очах грома- дянства», здійснений товариством «Взаємна поміч українського вчительства»: будівництво у Ворохті в 1914-1928 рр. та в Черчі у 1929-1935 рр. «осель», які вписали яскраву сторінку в історію розвитку суспільної медичної опіки українства краю. «Зорганізоване вчительство» (з опорою на власні сили) зуміло завдяки «великій жертовності» («поголовний» внесок членів ВПУВ у розмірі 20 зл., який міг сягати і 20 \% від заробітку українського вчителя) зібрати для «зведення» двох осель понад 200 тис. зл. [6, 7, 13-15].

Попри те, що «оселі» не пропонували спеціального медичного лікування, однак тут допомагали «особам» «у початках недуги, фізично вичерпаних, бажаючих зміцнити організм і відпочити, а також для здорових осіб, які шукають приємности побуту серед гір, гігієнічних розривок і товариства». Ці оздоровлювально-лікувальні заклади стали також важливими осередками української культури: улітку влаштовували курси самоосвіти вчительства та численні різноманітні «виклади» і товариські [6, 7, 13-15].

Аналогічні проекти зведення власної оселі тривалий час виношувала «Учительська громада», проте перешкодою в цьому стали нечисленність товариства і розпорошеність його місцевих організацій: станіславська філія звела «віллу» «Маковиця» у Ямній, тернопільська - у Рожанці (Карпати). Товариство письменників і журналістів упродовж 10 років через пресу активно закликало громадськість надати допомогу в будівництві санаторію в Ямниці, проте це не увінчалося успіхом: збір коштів не змогли завершити [2, 15].

У статті «Живець Черче» [9], уміщеній у щоденнику «Діло» (1930, 5 липня), І. Куровець описує свою мандрівку 29 червня 1930 р. до «українського живця Черче», «щоби побачити його наочно та пізнати його лічничу вартість». Наведемо окремі «оцінки» знаного лікаря та громадського діяча, щоб з'ясувати напрями діяльності «живця». Процитуємо: «Корисну оцінку про лічничу вартість черчанських вод і боровини видали д-р Панчишин, доцент університету д-р Сабатовський, бальнеолог та інші»; «хворі, які там перебували, хвалять собі черчанські води у ріжних недугах»; «При в’їзді з горбів до Черча робить воно симпатичне вражіння чистого малого містечка, в якій видніють гарні лічничі заведення, павільйони, а далі мурована церква, великий поверховий Народний Дім, в якім містяться місцеві культурні й економічні 
товариства»; «Симпатично вражають ... приватні мешкальні павільйони і всі купелеві будинки, що є чисті і гарні»; «Перед головним будинком великий майдан, хідники і квітники, утримані в порядку. Недостає зелені, а то корчів і дерев...»; «Всюди чути гамір, сміх і веселість». Автор публікації зазначає, що тут оздоровлюються відомі галичани, 3-поміж яких священики, Теофіл Окуневський та інші, які «шукають порятунку здоров’я і хвалять черчанські води», та наголошує на великій фаховості «солідного» «закладового лікаря д-ра Чаплинського», який добре «дбає про здоров’я хворих» [9].

Як науковець, I. Куровець, який особисто переконався на «здоровній силі черченського «живця» («пробував води всіх джерел, випив близько 8-10 шклянок»), застерігає від «дикого лікування», підкреслює, що споживати лікувальну воду потрібно «тільки за приписами лікаря» та дає рекомендації щодо здійснення санаторійно-лікувального догляду та медичної опіки: «Управа повинна видати строгий регулямін, щоби кожний приїжджаючи хворий зголосився до лікарських оглядин і певних відступах часу був огляданий лікарем. Безумовно мусить бути заборонене дике лікування, уживання вод і купелів без поради закладового лікаря. Лікар повинен бути обов’язаний вести докладний спис хворих та їх недуг, і мати точну евіденцію про кожного хворого та про наслідки лікування. Статистику хворих і висновки лікаря повинна управа оголошувати по закінченні купелевого сезону в часописах» [9].

Зважаючи на численні позитивні відгуки хворих, які повністю «вдоволені лікуванням», «з порядку і чистоти цілого заведення», а також на основі спостережень над тим, як «управа дбає про розвій Черча», з огляду на те, що «фреквенція хворих піднялася цього року майже втроє», I. Куровець радить очільникам «живця» розширюючи розбудову закладу, також «з часом поглибити верчення боровин, так само поглибити і прослідити поодинокі джерела та їх обіймати, а опісля поробити хемічні точні аналізи». І робить справедливий висновок: «Черче має перед собою будуччину, але ще треба великого вкладу гроша і праці». Поради I. Куровця щодо перспективного розвитку «живця» довело майже 80-річне існування санаторію, який активно розвивається сьогодні, а «помічення» про зведення «павільйона» для хворих (заможних) євреїв, що спричинить додаткові інвестиції [9], та інші «оцінки» варто «взяти під увагу» і сьогоднішнім орга- нізаторам санаторійно-оздоровлювальної справи в Карпатах.

Один із векторів просвітницької роботи ідеологи українських громадських товариств спрямували на галицьку родину та на жінку як хоронительку «домашнього огнища» $\mathrm{i}$ «виховницю» дітей, яка несе відповідальність за їхній розвиток. Акцентувалося на організації здорового харчування, «відживлювання», розширенні «хатнього меню» за рахунок споживання вітамінів, городини, фруктів, продуктів меду тощо [2]. Українські інституції, передусім товариство «Відродження», жіночі (Союз українок та ін.), освітні («Українська захоронка», ТВО, УПТ «Рідна школа») організації не виробили цілісної програми здоров’язбереження дітей, проте їхні діячі добре розуміли значущість цієї проблеми. Так, лікарі-активісти, освітяни С. Окуневська, С. Парфанович, К. Малицька та інші закликали наповнити діяльність українських дошкільних закладів «новим змістом», щоб «вберегти маленьких дітей від моральних і фізичних шкод», виховати їх у любові до рідної землі, України, нації. У цьому вбачала одну з ключових засад збереження української дитини для своєї нації [11]. Українські приватні заклади освіти, улаштовані УПТ «Рідна школа» та УГКЦ, постійно перебували під медичним наглядом та опікою українських лікарів, які здебільшого безкоштовно надавали лікарську допомогу учнівству [2].

Окрему сторінку в історію становлення і розвитку здоров’язбереження вписали українські інституції, греко-католицьке духовенство, особливо митрополит А. Шептицький, ідеться насамперед про створення системи медичної опіки та оздоровлення дітей шляхом організації літнього відпочинку, зокрема в літніх «півоселях» у Коршеві, Милованні (Станіславівщина), де проводили акцію «відживлювання» дошкільників та учнів [4, 5, 11, 13, 14]. За даними часопису «Діло» за 1938 р., упродовж 34 років близько 100-140 дітей кожного літа набиралися сил, здоров’я та пізнавали особливості сільського життя та праці в Милованню та Коршеві [13]. Освітню, виховну й оздоровчу мету перебування дітей у літніх «оселях» ідеологи ТВО, УКТОДОМ, УПТ «Рідна школа» бачили не тільки в «рум'яних личках дітвори, збільшеній вазі тіла», а й у «національному освідомленні міської дітвори [2, 4, 5, 11, 13, 14], оздоровчі заклади кваліфікували як важливу ланку суспільної опіки зростаючої особистості.

Абсолютно новим напрямом у системі суспільної медичної опіки стала «здоровна опіка» дітей 
та юнацтва. Оскільки про це частково йшлося в контексті аналізу діяльності «Медичної громади» та УГТ, наразі наголосимо лише на здійсненні медичного нагляду і ділянці тіловиховання (фізичного виховання і спорту. - авт.) українського юнацтва. Із цією метою у травні 1931 р. (за деякими даними, 1930 р. [8]) була створена спеціальна «спортово-лікарська порадня» у Львові, яка працювала 3-4 рази на тиждень. Завдяки подвижницькій праці лікарів (I. Мриц, С. Коцюба, С. Коренець, Б. Макарушка) уперше в історії розвитку українського медичного руху та суспільної медичної опіки здійснювався фаховий профілактичний огляд членів спортивних та інших громадських товариств («Сокіл-Батько», «Український спортовий союз» (УСС), КАУМ «Орли» тощо), понад те, систематично та постійно за скеруванням шкільних лікарів чи вчителів руханки медики надавали різного роду фахову допомогу. Лікарі «порадні» брали участь у проведенні спортивних змагань [8]. Це відображає єдина віднайдена нами розвідка «Медики в українському тіловиховному русі» Р. Копача, громадського діяча Галичини, активіста пластового руху, організатора пластових куренів [8]. У ній автор зазначає, що очільники українського тіловиховання, «головно проф. І. Боберський, звернули увагу ...на стремління та досягнення інших европейських народів у ділянці тіловиховання та вказували шлях розвою нашому тіловиховному рухові» [8].

Один із таких «шляхів» підказало саме життя. Оскільки «лікарі та медики, будучи молодими, самі брали участь у різних тіловиховних вправах», а багато з членів «Медичної громади» не повернулося з національно-визвольних змагань, багато не змогло закінчити свого навчання через «тяжкі своєрідні повоєнні обставини» (як, до прикладу, Степан Гайдучок та Тиміш Блостоцький), то колишні студенти-медики стали «професорами руханки». Здобуті медичні знання вони застосували «при своїй тіловиховній праці». Р. Копач наводить приклади членів «Медичної громади», які активно «працювали над розвитком тіловиховання: Степан Коцюба, б. начальник Сокола-Батька, автор підручника «Будова руханкових приладів» і інших підручників, та Іван Мриц, один з найкращих лещатарів, автор підручника «Наука їзди на лещатах» [1, 8, 10, 16]. На сторінках часопису «Українське юнацтво» (1933-1939) ми віднайшли низку прізвищ «знаних у краї змагунів» - членів «Медичної громади»: І. Круль - митець «у стусані кулею», Р. Рак - «визначний спрінтер», В. Семків - «митець «у метанні диском». Українських лікарів бачимо і 3-поміж «дружини» (складу. - авт.) чи керівництва футбольних клубів, до прикладу, лікар д-р Дутковський - надавав медичну опіку футбольному клубові «Бескид» (Надвірна, Станиславівщина), Я. Хмілевський - був у проводі «Пролому» (відомий футбольний клуб Станиславова) та ін. [8]. 3 метою популяризації ідеї тіловиховання 3-поміж юнацтва 1931 р. «Медична громада» «фундує чашу - мандрівну нагороду для українського студента першуна в ситківці» (волейбол. - авт.).

Вважаємо, що заслуга лікарів та студентів медицини полягає у пропагуванні ідеї здоров'язбереження, власним прикладом вони та очільники чи активісти українського тіловиховного руху спричинилися до виховання здорового способу життя, залучення до тіловиховання не тільки юнацтва, а й «іуніорів», тобто підлітків, а також дівчат. За словами О. Гайського, український тіловиховний рух «став заборолом проти переходу нашої молоді до місцевого польського спорту («Стржельца»), вдержуючи її по нашому боці і спрямовуючи її в русло українського громадського життя» [3].

«Медики-суспільники», «змагуни» слугували прикладом фізичної та моральної досконалості, здорового способу життя, були «ідейниками», «просвітниками», вони проводили громадську просвітницьку працю з-поміж краян, їхні спортивні турне перетворювалися на мандрівні агітаційно-пропагандистські бригади, тематика яких була «глибоко національного змісту», де окреме місце посідала проблема культу здоров’я. Висновок робимо на підставі інформації про розвиток українського тіловиховного руху на Станиславівщині. У спогадах О. Гайського [2], С. Побратима [1], уміщених в «Альманасі Станиславівської землі», читаємо, до прикладу: «Ідейна, чи ідеалістична сторінка віддзеркалювалася в постанові не курити монопольного державного тютюну... Станиславівський УСК ... їдучи на змагання до інших місцевостей, за дня грав у футбол, а вечером презентував місцевим українцям ревію, чи солідну сценічну п’єсу, яку підготовляла Слава Барнич, а головні ролі виконували філяри УСК -у і УСС-у: Ярослав Андрухович, Тарас Ліськевич, Степан Зубаль, Ліда Каратницька (тепер Крушельницька), Ірка Барнич (тепер Дубас), Ірка Лисяк (тепер Стрийська) і багато інших... Душею 
цієї амфібійної діяльности в спорті і на сцені був Ярослав Андрухович... майже все це були «студенти спорту», тобто люди, що цікавилися теорією й розвитком спорту, держали руку на живчику актуального всесвітнього спорту й активно вправляли інші роди спорту...» [3].

Український тіловиховний рух здобував своїх «симпатиків» 3-поміж дорослого населення, яке за 1920-х років вважало його «невидальщиною», що не дає «ніякої користи» і не має «ніякого глузду в таких дітвацьких забаганках» [1, 2], то вже за 1930-х рр. спорт збирав повні сільські та міські «аншлаги, «спортивний ентузіязм ... був такий, що в час змагань злодії - яких, на щастя, мабуть не було - могли винести з кожної хати все добро: місто було на змаганнях у Богородчанах» [3].

Спортивне товариство «Прут» у містечку Делятині (Станиславівщина), яке виникло на межі 19201930-х років, окрім футболу, розвивало й інші види спорту («діяльними були ланки лещатарська, шахова, пінг-понгова») та дбало про всебічний розвиток юнацтва ( «ланки культурно-освітня, з драматичним гуртком, який прибутками зі своїх п’єс фінансував спортову працю; діяльною була мандоліново-гітарна оркестра, ведено курси народних танків»). Як бачимо, спортивний клуб перетворився на центр самоосвіти, розвитку мистецтва, цікавого й змістовного дозвілля юнаків та дівчат» $[1,3]$.

М. Небелюк, активіст українського тіловиховного руху, у спогадах описує зацікавлення ідеєю лещатарства гірськими мешканцями, яку за 1930 р. пропагували ідеологи українського тіловиховного руху $[1,3,8,10,16]$, а також розвиток «дівочої відбиванки».

Отже, «пластуни», «медики-суспільники», «спортовці» стали своєрідними суспільними просвітниками, залучили до праці юнацтво міста й села «у сприятливій для всіх і корисній для спільноти формі організованого життя», створивши школу тіловиховання з гармонійним поєднанням «масового з вершинним» спортом, допомогли «зберегти по містах нашу молодь» «по наш бік», а своїми здобутками «над чужинцями» «допомогли вдержати в масах віру в остаточну перемогу українства над окупантом, а вихідці-емігранти понесли славу українського спорту і національного ймення далеко в світ» [3].

Ідея тіловиховання (через мандрівництво і таборування, заняття спортом) як складник здоров'я- збереження українства посіла провідну позицію на початку XX ст., особливі успіхи вона принесла за 1930-х рр., коли до тіловиховного руху долучалося все ширше коло українського юнацтва, а «доросле громадянство» виявляло до нього не упереджене ставлення, а зацікавлення. «Пластуни», «соколи», «змагуни», студенти-медики слугували прикладом для наслідування та переконували краян у необхідності ведення здорового способу життя («здорова одиниця - здорова нація»).

Висновки та перспективи подальших досліджень. За досліджуваного періоду в Карпатському регіоні склалася система масового громадського медичного просвітництва, що охоплювало всі напрями системи медичної опіки (санітарно-гігієнічний сегмент, здоров'язбереження та тіловиховання, рух тверезості тощо), яка постійно еволюціонувала та вдосконалювалася. Означені напрями праці були реальним внеском у збереження генофонду українського народу. Створена система лікувально-профілактичних (диспансери, амбулаторії, шпиталі, лабораторії) та консультативних («порадні») закладів засвідчила важливість організації суспільної медичної опіки українців, тут могли отримати безкоштовну (чи за символічну оплату) найменш незахищені (та найбільш вразливі до соціальних катаклізмів) верстви українства (діти, учасники національно-визвольних змагань українців, інваліди, удовиці, сироти, селянство, українське вчительство, студентство та ін.). Складником філософії здоров'язбереження українства була ідея тіловиховання. Ефективним засобом і формою здоров'язбереження в Галичині стало оздоровлення дітей та дорослих в «оселях», «півоселях», «живцях» та інших суспільних закладах, що виконували оздоровчі й лікувальні функції. Українські громадські (зазвичай станові) товариства вагомо спричинилися до організації відпочинку для своїх членів, а також забезпечення оздоровлення (зазвичай міських дітей) у гірській місцевості. Предметом подальших досліджень можуть стати проблеми підготовки фахівців до здійснення гігієнічного виховання дітей та дорослих у Галичині в першій третині XX ст.; зміст, методи, форми антиалкогольного виховання в молодіжних товариствах Галичини (кінець ХIX ст. - 1939 р.) та ін. 


\section{Список літератури}

1. Альманах Карпатського Лещатарського Клюбу 1924-1984. - Львів ; Мюнхен ; Нью-Йорк, 1989. - 240 с.

2. Білавич I. Передумови створення громадського медичного просвітництва та лікарської опіки в Галичині на початку XX ст. / Іван Білавич // Молодь і ринок. - 2015. № 1. - С. 133-136.

3. Гайський О. Тіловиховання і спорт / О. Гайський // Альманах Станиславівської землі. Збірник матеріалів до історії Станиславова і Станиславівщини / редактор-упорядник Богдан Кравців. - Нью-Йорк ; Торонто ; Мюнхен, 1975. - С. 341-381.

4. Далекий О. Дві дитячі півоселі / О. Далекий // Діло. 1938. - 4 вересня.

5. Далекий О. Як 140 українських дітей віджило в сонці й повітрі / Остап Далекий // Діло. - 1938. - 4 вересня.

6. Звідомлення з діяльности Тов-ва «Взаїмна Поміч Українського Вчительства» за 1937 рік // Учительське слово. - 1938. - Ч. 8-9. - С. 87-105.

7. Звідомлення з діяльности Тов-ва «Взаїмна Поміч Українського Вчительства» за 1938 рік // Учительське слово. - 1939. - Ч. 10. - С. 130-145.

8. Копач Р. Медики в українському тіловиховному русі / Р. Копач // 25-ліття Українського Лікарського Товариства і Медичної громади. - Чікаго, 1975. - Репринтне видання 1935 року. - С. 103-104.

9. Куровець І. Живець Черче. Мої враження і помічення / Іван Куровець // Діло. - 1930. - 5 липня.

10. Лещетарство. КЛК // Українське юнацтво. - 1935. Ч. 3. - C. $46-47$.

\section{References}

1. (1989). Almanakh Karpatskoho Leshchatarskoho Klubu 1924-1984 [Carpathian ski club almanac 1924-1984]. LvivMunchen-New-York [in Ukrainian].

2. Bilavych, I. (2015). Peredumovy stvorennia hromadskoho medychnoho protsvitnytstva ta likarskoi opiky v Halychyni na pochatku XX st. [Prerequisites for the establishment of public medical education and medical care in Galicia in the early XX century]. Molod i rynok - Youth and Market, 1, 133-136 [in Ukrainian].

3. Haiskyi, O. (1975). Tilovykhovannia i sport [Physical education and sports]. Almanakh Stanyslavivskoi zemli. Zbirnyk materialiv do istorii Stanyslavova i Stanyslavivshchyny - The Stanislav land Almanac. Collection of Materials on the History of Stanislaviv and Stanislaviv region. Kravtsiv, B.(Ed.). New-York-Toronto-Munich [in Ukrainian].

4. Dalekyi, O. (1938). Dvi dytiachi pivoseli [Two children's settlements]. Dilo-Case [in Ukrainian].

5. Dalekyi, O. (1938). Yak 140 ukrainskykh ditei vidzhylo v sontsi y povitri [How 140 Ukrainian children survived in the sun and air]. Dilo - Case [in Ukrainian].
11. Малицька К. Починаймо будувати від основ / Костянтина Малицька // Громадський вістник. - 1922. Ч. 55. - С. 7.

12. Озаркевич $Є$. Наші кліматичні станції / Є. Озаркевич // Є. Озаркевич. Праці / [упоряд. Я. Ганіткевич, П. Пундій]. - Львів, 2005. - С. 172-182.

13. Тиждень Української Дитини // Діло. - 1925. 6, 7 травня.

14. Товариство «Вакаційні Оселі» // Діло. - 1930. 24 квітня.

15. Товариство Взаїмна Поміч Українського Вчительства 1905-1930. - Львів, 1932. - 339 с.

16. Ю. С. Краєві лещетарські змагання в Славську / Ю. С. // Українське юнацтво. - 1937. - Ч. 3. - С. 48-50.

17. Hilarowicz T. Zarys polskiego prawa sanitarnego / T. Hilarowicz. - Warszawa, 1926. - 104 s.

18. Grodecki M. Stan walki z grużlią c na ziemiach polskich / M. Grodecki // V Ogólnopolski Zjazd Przeciwgruźliczy. Pamiętnik. - Warszawa, 1934. - S. 233-357.

19. Kacprzak M. Ośrodki zdrowia w Polsce / M. Kacprzak. Warszawa : Drukarnia kooperatywy Pracowników drukarskich, 1928. - $115 \mathrm{~s}$.

20. Leszczycki S. Podstawy gospodarki uzdrowiskowoletniskowej w Karpatach. - Warszawa, 1939. - 64 s.

21. Leszczycki S. Przemysł uzdrowiskowo-letniskowy i tyrystyczny w Karpatach. - Warszawa, 1938. - 24 s.

6. (1938). Zvidomlennia z diialnosti Tov-va "Vzaimna pomich Ukrainskoho vchytelstva” za 1937 rik [Report on the activity of Society "Mutual assistance of the Ukrainian teachers” for 1937]. Uchytelske slovo - Teacher's Word, 8-9, 87-105 [in Ukrainian].

7. (1939). Zvidomlennia z diialnosti Tov-va "Vzaimna pomich Ukrainskoho vchytelstva” za 1938 rik [Report on the activity of Society "Mutual assistance of the Ukrainian teachers” for 1938]. Uchytelske slovo - Teacher's Word, 10, 130-145 [in Ukrainian].

8. Kopach, R. (1975). Medyky v ukrainskomu tilovykhovnomu rusi [Physicians in the Ukrainian physical education movement]. 25-littia Ukrainskoho Likarskoho Tovarystva i Medychnoi hromady - 25th Anniversary of the Ukrainian Medical Society and the Medical Community. Chicago [in Ukrainian].

9. Kurovets, I. (1930). Zhyvets Cherche. Moi vrazhennia i pomichennia [Cherche Spring. My impressions and observations]. Dilo - Case [in Ukrainian].

10. (1935). Leshchetarstvo. K.L.K. [Skiing]. Ukrainske yunatstvo - Ukrainian Youth, 3, 46-47 [in Ukrainian]. 
11. Malytska, K. (1922). Pochynaimo buduvaty vid osnov [Let's start building from the basics]. Hromadskyi visnyk Public Bulletin, 55, 7 [in Ukrainian].

12. Ozarkevych, Ye. (2005). Nashi klimatychni stantsii [Our climatic stations]. Ye. Ozarkevych. Pratsi - Works of Ye. Ozarkevych. Lviv [in Ukrainian].

13. (1925). Tyzhden Ukrainskoi dytyny [The week of Ukrainian child]. Dilo - Case, [in Ukrainian].

14. (1930). Tovarystvo "Vakatsiini Oseli" [Holiday homes society]. Dilo - Case [in Ukrainian].

15. (1932). Tovarystvo Vzaimna Pomich Ukrainskoho Vchytelstva 1905-1930 [Mutual assistance of the Ukrainian teachers society 1905-1930]. Lviv [in Ukrainian].
16. Yu., S. (1937). Kraievi leshchetarski zmahannia v Slavsku [Regional ski races in Slavsk]. Ukrainske yunatstvoUkrainian Youth, 3,48-50 [in Ukrainian].

17. Hilarowicz, T. (1926). Zarys polskiego prawa sanitarnego. Warszawa.

18. Grodecki, M. (1934). Stan walki z grużlią c na ziemiach polskich. V Ogólnopolski Zjazd Przeciwgruźliczy. Pamiętnik. Warszawa.

19. Kacprzak, M. (1928). Ośrodki zdrowia w Polsce. Warszawa: Drukarnia kooperatywy Pracowników drukarskich. 20. Leszczycki, S. (1939). Podstawy gospodarki uzdrowiskowo-letniskowej w Karpatach. Warszawa.

21. Leszczycki, S. (1938). Przemysł uzdrowiskowoletniskowy i tyrystyczny w Karpatach. Warszawa.

Електронна адреса для листування: fedushunno@tdmu.edu.ua 